\title{
2011: o Antes e o Depois
}

Nos primeiros meses da presente Administração da SBQ, foi realizado um planejamento estratégico envolvendo a Diretoria e o Conselho Consultivo. A missão, a visão, os princípios, o ambiente externo (oportunidades e ameaças), o ambiente interno (pontos fortes e pontos fracos) da Sociedade foram levantados e discutidos.

A partir desse autoconhecimento, formularam-se cinco questões estratégicas, consideradas urgentes e de impacto à Sociedade: i) como promover o fortalecimento da SBQ? ii) como melhorar e ampliar o apoio da SBQ ao seu associado? iii) como incrementar as relações e atuação da SBQ junto a entidades similares? $i v$ ) como promover a atuação da SBQ na contribuição ao desenvolvimento sustentável da sociedade? $v$ ) como implantar um projeto de comunicação e marketing para a SBQ?

As ações da atual administração buscaram, além de cumprir com a plenitude possível suas finalidades associativas, responder concretamente às questões elencadas.

Na 35 RASBQ, tomarão posse os novos Dirigentes e Conselheiros, em todos os níveis organizacionais da nossa Sociedade, para o período 2012-2014 e, inevitavelmente, surgem expectativas relacionadas com os rumos da Sociedade que, dependendo do olhar (sensibilidade) de cada sócio, podem ser positivas ou não.

O novo Estatuto vigora, pela primeira vez, em eleições. Destacam-se, como inovações, as escolhas do President to be e do Conselho Fiscal, instrumentos com fins explícitos de preservar a estabilidade institucional da Sociedade e de garantir a pluralidade de opiniões e a transparência administrativa. A aprovação e a implantação desse novo Estatuto foram resultado do planejamento estratégico.
As ações formuladas para o alcance das metas associadas às questões estratégicas foram planejadas tendo como principal referencial o ano internacional da Química, AIQ-2011, que teve uma preparação prévia (e longa) e supõe, necessariamente, um conjunto de ações pós-AIQ, como única forma de perpetuar, junto à comunidade química e à sociedade civil, o papel indispensável duma boa e vigorosa Química ao desenvolvimento e ao bem-estar social.

O AIQ-2011 foi um marco histórico da Ciência Química: daqui para o futuro, creio, enxergaremos o antes e o depois de 2011. Por isso, vale relembrar os principais acontecimentos e realizações desse referencial.

A $34^{\mathrm{a}}$ RASBQ foi um evento especialmente concorrido e animado. Fato inédito foi a significativa presença de químicos estrangeiros, dentre os quais os presidentes da IUPAC, da ACS e da RSC, que participaram ativamente de debates e/ou proferiram palestras. O comparecimento de representantes das Sociedades Co-Irmãs deveu-se, em parte, à inserção internacional da SBQ - meta trabalhada há anos e que muito avançou no último biênio. O número de participantes, mais de 4.500, também foi resultado da ampliação e fidelização do quadro social, que aumentou em $20 \%$ nesses dois anos, baseado no fortalecimento das Regionais e das Divisões Científicas, bem como na participação colaborativa e no comprometimento dos associados.

Nacionalmente, a SBQ capitaneou as ações do AIQ-2011. O congraçamento e o trabalho cooperativo entre os inúmeros agentes nacionais dedicados à Química (CRQs, Associações, Universidades, Órgãos representativos da Academia e da Indústria Química, Museus e Casas da Ciência) e a adesão de milhares de sócios e professores do ensino médio levaram à 
realização de atividades científicas, objetivando a divulgação e a popularização da Química.

Foram registradas centenas de atividades no portal www.quimica2011.org.br, coordenado pela SBQ e com mais de 500 mil visitas em 2011. Tiveram forte repercussão social projetos como $o \mathrm{pH}$ do Planeta e o DVD - Projeto da SBQ, 80 mil unidades distribuídas pelo MEC, com coleções da QNesc, Química do Cotidiano (sete livros), Química perto de Você, Experimentos para sala de Aula do Ensino Básico, a Exposição Química do Cotidiano e 365 Dias de Química.

Dezenas de palestras e conferências foram proferidas por cientistas brasileiros e estrangeiros convidados, entre os quais vários Prêmios Nobel de Química. Os Fóruns dos Coordenadores de Cursos de Graduação e dos Programas de Pós-Graduação em Química realizaram, pela primeira vez, encontro conjunto, cuja temática principal foi a educação em Química e a formação do Químico, com claras inserções estimulando o desenvolvimento da Química pura e da solução de problemas químicos atuais (inovação), que vise à sustentabilidade por meio da Química Verde.

As nossas revistas (JBCS, QN, RQV), com a missão de serem os melhores veículos de divulgação do avanço científico da Química e, especialmente, a QNesc e a QNint, de educação em Química, responderam ao estímulo do AIQ, ocupando o espaço e o público que lhes é devotado.

As mídias sociais dedicaram-se, também, à popularização da Química, em 2011: Facebook
(AIQ2011): 2.131 seguidores e 756.694 visualizações de páginas; Twitter (@aiq2011): 1.468 seguidores e 1.519 tweets; Blog (http://blog. quimica2011.org.br): cerca de 22 mil visitas; imprensa brasileira: mais de 1.000 inserções.

A SBQ aproveitou, nos últimos dois anos, as oportunidades midiáticas nos momentos importantes: no lançamento do AIQ, em janeiro de 2011, em Paris, a Comitiva Brasileira era amplamente formada por representantes da $\mathrm{SBQ}$, que receberam tratamento diferenciado da IUPAC; em março de 2011, o Lançamento Nacional do AIQ, na ABC - RJ, foi uma solenidade ímpar, com repercussão nacional e no encerramento, em dezembro último, em Bruxelas, novamente a SBQ foi reconhecidamente aplaudida.

Em agosto do corrente ano, a SBQ, como a única Organização Brasileira associada à IUPAC, realizará a $4^{\text {th }}$ International IUPAC Conference on GREEN CHEMISTRY, em Foz do Iguaçu/PR.

A contundência das ações da SBQ em prol da ciência Química, suas aplicações e divulgação, a credencia a postular, no seu $40^{\circ}$ Aniversário, com o apoio declarado das principais Sociedades Internacionais Co-Irmãs, a realização, no Brasil, em 2017, do $46^{\circ}$ Congresso e a $49^{\text {a }}$ Assembleia Geral da IUPAC. A proposta concorrente da SBQ estará sendo enviada à IUPAC, neste mês de abril, caracterizando uma das ações para o depois de 2011.

César Zucco

Presidente da SBQ 


\section{1: Before and Afterwards}

During the first months of the current administration of the Brazilian Chemical Society (BCS), a strategic planning was developed, involving the Board of Directors and the Advisory Board. The Society's mission, vision, principles, external environment (opportunities and threats), internal environment (strong and weak points) were all raised and discussed.

Out of that self-awareness, five strategic issues, considered urgent and socially impacting were formulated: $i$ ) how to promote the BCS strengthening? ii) how to improve and expand the support of the BCS to its members? iii) how to foster the relations and performance of the BCS with similar entities? iv) how to improve the BCS contribution towards the sustainable development of society? $v$ ) how to establish a project of communication and marketing for the BCS?

Besides fulfilling, as completely as possible, its associative purposes, the present Administration has attempted to effectively respond to the listed issues.

In the $35^{\text {th }}$ Annual Meeting of the BCS (RASBQ), the new Directors and Counselors, in all levels of our Society, will take office for the 2012-2014 period and, inevitably, expectations concerning the directions of the BCS arise, which, depending on the viewpoint (sensitivity) of each member, can be positive or negative.

For the first time, the new Statute is in force for the elections. Among the innovations, we can point out the choices of the President to be and of the Fiscal Board as instruments with the explicit aim of preserving the BCS institutional stability and of guaranteeing the plurality of opinions and the administrative transparency. The approval and establishment of the new Statute resulted from the strategic planning.
The actions formulated in order to reach the goals related to the strategic issues were planned having as a referential basis the International Year of Chemistry, IYC-2011, which had a previous (and long) preparation and which, necessarily, implies a set of post-IYC actions, as the only way to perpetuate along with the chemistry community and civil society the indispensable role of a good and vigorous Chemistry towards the social development and welfare.

The IYC-2011 was a historical landmark for the Chemical Science: from now on, I believe, we will have the before and the after 2011. That is why it is worth recalling the main events and achievements of this benchmark.

The $34^{\text {th }}$ RASBQ was a particularly well-attended and exciting event. Unprecedented was the significant presence of foreign chemists, among those the IUPAC, ACS and RSC's presidents, who actively participated debating and/or delivering lectures. The attendance of representatives of Co-Sister Societies was, in part, due to the international insertion of the BCS- a goal long sought after and that greatly improved in the last biennium. The number of participants (more than 4,500) was also the result of the expansion and retention of membership, which has increased $20 \%$ in the last two years, thanks to the strengthening of the Regional Sections and Scientific Divisions, as well as to the members' commitment and collaborative participation.

Nationally, the BCS led the actions related to the IYC. The interaction and cooperative work among the several national agents dedicated to Chemistry (Regional Chemical Councils, Associations, Universities, Entities representative of the Academy and of the Chemical Industry, Museums and Houses of Science), as well as the adhesion of thousands of 
members and high school teachers have led to the accomplishment of scientific activities that aimed at making Chemistry more known and popular.

Hundreds of activities were registered at the website www.quimica2011.org.br, supervised by the BCS, with over 500 thousands visits in 2011. Great social impact was achieved by projects such as the $\mathrm{pH}$ of the Planet and the DVD - Project of the BCS, 80 thousand of which were distributed by the Ministry of Education and Culture with collections of the journal QNesc (Chemistry in the school), Chemistry of Everyday Life (seven books), Chemistry near you, Experiments for the Elementary School Classroom, the Everyday Chemistry Exposition and 365 Days of Chemistry.

Dozens of lectures and conferences were given by Brazilian and foreign invited scientists, including several Chemistry Nobel Prize Laureates. Coordinators of both Undergraduate Courses and Graduate Programs met together for the first time in Forums, the main theme of which was the education in Chemistry and the Chemist formation, clearly stimulating the development of the pure Chemistry and of the solution of present chemical problems (innovation), aiming at sustainability by means of the Green Chemistry.

Our journals (JBCS, QN, RQV), the mission of which is to be the best vehicles for disseminating the scientific development of Chemistry and, mainly, QNesc and QNint, on Chemistry education, responded to the IYC stimulus, filling in the empty space and reaching the interested public.
The social media were also dedicated to popularizing Chemistry in 2011: Facebook (IYC2011): 2,131 followers and 756,694 page views; Twitter (@iyc2011): 1,468 followers and 1,519 tweets; Blog (http://blog. quimica2011.org.br): about 22 thousand visits; the Brazilian press: over a thousand inserts.

In the last two years, the BCS took advantage of mass medium opportunities in important moments: at the launch of the IYC, in Paris, in January 2011, the Brazilian delegation was largely made up by the BCS representatives, who received a special treatment from the IUPAC; in March 2011, the Nationwide Launch of the IYC at the Brazilian Academy of Sciences, in Rio de Janeiro, was a unique event, with national impact and at its close, in Brussels, last December, once more the BCS was indebtedly applauded.

Next August, the BCS, as the only Brazilian Organization associated to the IUPAC, will hold the $4^{\text {th }}$ International IUPAC Conference on GREEN CHEMISTRY, in Foz do Iguaçu, Paraná, Brazil.

The BCS decisive actions in favor of the Chemical Science, its applications and dissemination accredit it to postulate, on its $40^{\text {th }}$ anniversary, the declared support of the main International Co-Sister Societies in order to hold, in Brazil, in 2017, the $46^{\text {th }}$ Congress and the $49^{\text {th }}$ General Assembly of the IUPAC. The BCS competing proposal will be sent to the IUPAC still in April, characterizing one of the actions for the after 2011.
César Zucco

BCS President 